\title{
J. Urbaniak
}

\section{RELIGIONS AS A SOURCE OF (DIS)ORDER}

\begin{abstract}
Would it be fair to say that religious people in general are more suspicious of the believers of other religions than of those who claim to have no faith at all? If the pivotal role of religiosity consists in bringing meaning and order to human life, why should different religions see their respective "orders" as threatening one another? Isn't it possible to trust in the midst of the multi-ordered reality of world faiths while acknowledging the presence (in all religions) of the untruth despite all the truth? This paper seeks to explore those and similar questions by means of elaborating on religions as potential contributors to a global ecumenism. Building upon insights of Charles Taylor and Hans Küng, I show in what sense the world religions can be considered the source of order as well as disorder and how the plurality of religiouslybased "orders" can be accepted and embraced with trust rather than suspicion.
\end{abstract}

I make a brief against the 'closure' of the confessional faiths, against allowing them to close the circle of faith, to slam shut the doors of faith from the intrusions of other faiths... to keep faith behind closed doors, safe and secure (Caputo 2001: 35-36).

This "manifesto" by John Caputo may galvanise the believers of all faiths into a thorough examination of conscience. Would it be fair to say that religious people in general are more suspicious of the believers of other religions than of those who claim to have no faith at all? I asked myself this puzzling question while having witnessed a conversation between my friend's younger sister and her grandmother, a practising Dutch-reformed Christian. Once it became apparent that the girl has a new boyfriend whose

Dr. Jakub Urbaniak, Research fellow: Dept Systematic Theology, University of the Free State, South Africa. St Augustine College. e-mail: J.Urbaniak@staugustine.ac.za 
name is Ahmed, the granny screamed with terror: "Don't you dare to bring a Muslim under this roof! Over my dead body!" When the girl explained that Ahmed, though of Arab origins, is not a Muslim but an atheist, the older woman said with relief: "Well, I hope he is a good boy." Another case in point are Christian protests in secular Europe or Australia against transforming churches into mosques, which do not find a parallel when the same churches are to be changed into museums or art galleries.

Isolated examples of religious intolerance based on a deep-rooted prejudice or perhaps traces of something more, namely a cross-cultural tendency among religious believers to approach the representatives of other traditions with an a priori mistrust? But if the latter is true, then what does it say about our understanding of religion qua religion? These initial questions led me to pondering the paradox of religious (dis)order. If the pivotal role of religiosity consists in providing a basic orientation, in bringing meaning and order to human life, why should different religions see their respective 'orders' as competing or even as threatening one another? Isn't it possible to trust in the midst of the multi-ordered reality of world faiths while acknowledging the presence (in all religions) of the untruth despite all the truth? (Küng, van Ess, von Stietencron \& Bechert 1986: xix)

This paper seeks to explore that question by means of elaborating on religions as potential contributors to a global ecumenism, which - as I will argue - the present already suggests and the future definitely demands. Building upon insights of Charles Taylor and Hans Küng, I intend to show in what sense the world religions can be considered the source of order as well as disorder and how the plurality of religiously-based "orders" can be accepted and embraced with trust rather than suspicion. I first describe religiosity as a challenge to the modern "immanent frame" (Taylor). Secondly, I reflect on the potential functions of religion (both desired and undesired) in terms of bringing (dis)order. Thirdly - and that is the very core of my analysis - I look at (dis)order stemming from religions conceived of in their plurality. Lastly, in conclusion, the dialectics of (mis)trust and (dis)order in the religious context is examined through the lens of Küng's notion of "fundamental (mis)trust".

My overall intention underlying this study is to contribute to the conversation on the conditions of interfaith encounter in the (post)modern context that could prevent the growth of religious fundamentalisms (and often resulting terrorism), or at least minimalise their extent. I join this ongoing interreligious dialogue as a Christian theologian, rooted in the Catholic Intellectual Tradition, who every day experiences both the blessings and the challenges related to the religious pluralism inherent in the South African society. I will argue that engaging in a genuine interfaith 
dialogue depends, among other things, upon the believers' capacity to embrace the multi-ordered reality of the world religions trustingly. ${ }^{1}$

\section{BOUND TO BE FREE: RELIGIOSITY AS A CHALLENGE TO THE IMMANENT FRAME}

For the purposes of this study, l'd like to set forth the quasi-definitions of a "religious believer" and a "theologian". Respectively, a religious believer is the one who internalises (i.e., discovers, accepts, and interprets) as well as externalises (i.e., gives outward existential shape to) the divine order and a theologian is the one who brings about both order and disorder in God. The latter can be understood radically, with reference to God's very nature. ${ }^{2}$ However, here I interpret it more modestly, namely in terms of theological hermeneutics: the exercise of "chasing the meaning" of the divine - to use Hans Frei's expression (1992: 16) - wherein "(dis)ordering" refers merely to the human notion of God. In this sense, a religious believer may be compared to a primitive man who by watching wild animals starts hunting himself or to a physicist who experimentally proves the waveparticle complementarity and based on that principle formulates the thesis that no sharp line can be drawn between the process of observation and what is observed. A theologian, in turn, may be compared to the designer and builder of an aqueduct or the constructor of a thermonuclear weapon. The demarcation line between the two is subtle yet graspable.

The divine order, while being internalised and externalised by the believer, becomes the dynamic principle of both one's own spiritual life as well as one's own way of being in and for the world. Thus religious faith appears as the "believer's absolute disposition toward the world, which shapes an entire 'form of life"' (Keightley 1976: 73). As insisted by Küng, such faith constitutes at once "an act of knowing, willing and feeling, a trust which includes an acceptance of message and person as true" (Küng 2008: 162). Being a personal commitment, faith binds the

1 In this paper, I refer mainly to Christianity. I believe, however, that my considerations can be applied in principle to the three great monotheistic religions. Applying them to other religious traditions (including a non-theistic Buddhism and Confucianism) would require a much broader and more nuanced theological approach.

2 For example, in the light of dipolar theism developed by process thinkers such as Charles Hartshorne, by making free rational choices human beings are believed to bring actual change in the very life of God who is eternal in character and purpose (abstract pole) but changing in the content of experience (concrete pole) (Barbour 1998: 294). 
person; or rather the person binds herself through faith. In contrast to what the etymological meaning of the Latin religare might suggest, from the Christian point of view the personal "bond" which religion is meant to bring about, protect, develop, and express in social and cultural terms does not serve to restrain or tie back the believer, but rather to set him or her free. Even though, negatively speaking, this specific form of adhering involves "being devoid of something", the positive aspect of "being freed to embrace the divine order" mustn't be overlooked. Put simply, instead of imposing "limits" (Grenzen), faith internalises and externalises the divine order by offering "boundaries" (Schranken) (Kant 2002:142).

Charles Taylor defines religious faith in a strong sense by a double criterion: the belief in transcendent reality, on one hand, and the connected aspiration to a transformation which goes beyond ordinary human flourishing on the other (Taylor 2007: 510). In our secular age, we have come to understand our lives as taking place within a self-sufficient immanent order, i.e., an order which can be (though certainly doesn't have to be) understood in its own terms, without reference to the "supernatural" or "transcendent". This is our "immanent frame", the modern picture which to paraphrase Wittgenstein - holds us captive. ${ }^{3}$ It generates a background, the sensed context in which we develop our beliefs, within whose terms our thinking is carried on, but which is often largely unformulated, and to which we can frequently, just for this reason, imagine no alternative (Taylor 2007: 549). With no doubt, the different structures we live in (scientific, social, technological, and so on) constitute such a frame in that they are part of a "natural", or "this-worldly" order which can be understood as a self-sufficing order. All these forms of impersonal order: the natural, the political, and the ethical can be made to speak together against religious faith in God as personal agent (Taylor 2007: 283). However, as Taylor insists,

...this order of itself leaves the issue open whether, for purposes of ultimate explanation, or spiritual transformation, or final sensemaking, we might have to invoke something transcendent. It is only when the order is 'spun' in a certain way that it seems to dictate a 'closed' interpretation (Taylor 2007: 594).

This modern, impersonal and disengaged, concept of reality as the constellation of immanent orders - cosmic, social, and moral - is radically challenged by a religious, personal and engaged, understanding of order as being ultimately grounded in a "transformative transcendence" (Taylor 2007: 543). 
The entire history of humankind can be read through the lens of a navigation between these two standpoints:

an "engaged" one in which we live as best we can the reality our standpoint opens to us; and a "disengaged" one in which we are able to see ourselves as occupying one standpoint among a range of possible ones, with which we have in various ways to coexist (Taylor 2007: 12).

One of the far-reaching implications of the modern secular disengagement, which is correlative to what Taylor names "objectification" (Taylor 1989: 159-64), is that reality conceived of as the constellation of immanent self-sufficient orders is deprived of its normative force for us, or at least the meanings it has for us in our lives are bracketed (Taylor 2007: 283).

\section{RELIGION AS AN AGENT OF (DIS)ORDER, FOR GOOD OR ILL}

Against such a background, two apparently contradictory sets of understandings of religion as an agent of (dis)order can be propounded. To underscore their dialectical character I label them as "blessed" and "cursed". 4

la. Religion can be seen as an agent of a "blessed order" if and insofar as it involves the objective categoricity of moral commands. The latter requires reference to the Unconditioned which alone can impose an unconditional obligation, and to the Absolute which alone can be absolutely binding (Küng 1980: 468-72). Those who see our modern "God-forsaken", "man-made" world (no need for an inclusive language in this case) in terms of immanence that admits of no beyond, those who think of "natural" order as self-sufficing and thus exclusive of a "supernatural" one, have no grounds to see reality as ethically ordered in an absolutely binding manner (Taylor 2007: 550-53). Such objective categoricity of moral commands can be warranted but through the religious claims being oriented to something putatively transcendent.

Ib. On the contrary, religion can be seen as an agent of a "cursed order" if and insofar as it renders possible and furthers the "domesticating" of God (the sacred) as a means of power and control or a cheap comfort. The dehumanising impact of religious fanaticism and fundamentalism is often due to the political entanglements of religion which betrays its

4 This dialectical character of religious (dis)order is pointedly reflected in the title of the one of David Tracy's books, namely Blessed Rage for Order (1975). 
inherent existential mission of providing a basic orientation and order to human life and starts serving to manoeuvre various horizontal orders. ${ }^{5}$ It will be no exaggeration to say that whenever religion is used by rulers as a political instrument instead of being lived out as faith and ethics, it ends up being abused and eventually degenerates into a tool of oppression. It was precisely such a perverted, "marketable" religion to which Bonhoeffer opposed his nonreligious interpretation. One of the somewhat unobvious aspects of his notion of "religionless Christianity" had to do with the necessity to protect the mysteries of the Christian faith against profanation (Bonhoeffer 1971: 286), i.e., against sliding into either other-worldliness or inwardness and thus becoming banal and shallow. In this sense, religious institutions should be responsible for preventing God (the sacred) from becoming "too available" and too entangled in worldly orders, that is to say, too commercialised, too self-evident and too amenable to the "evangelistic sales pitch" (Urbaniak 2014a: 479).

IIa. On the other hand, religion can be seen as an agent of a "cursed disorder" if and insofar as it legitimates and fosters self-centredness instead of other-centredness. Internalising and externalising the divine order - what I have defined as the essence of religiosity - requires selfemptying (kenosis) for the sake of the other, whether it expresses itself through sharing in the redemptive suffering of Christ whose own sacrifice stemmed from and reflected the self-giving nature of the triune God, or through growing in a universal sympathy and peaceful benevolence towards every sentient being which is an essential aspect of following the Buddhist Dharma. John Hick is right to argue that all great traditions seem to occasion a radical turn from self-centeredness to Reality-centeredness (1989: 240). If religion does not lead to such a turn, it de facto replaces the personal and engaged order of transforming relation with a disengaged egocentrism which doesn't allow the human person to grow through communion, be it vertical or horizontal. Such perversion of religiosity not only hinders one from going beyond ordinary human flourishing, but also condemns the self to the chaos of its own finitude, experienced as being at odds with its infinite longings. Hence, it brings about a 'cursed disorder' within the apparently self-sufficing self.

IIb. On the contrary, religion can be seen as an agent of a "blessed disorder" if and insofar as it performs a function of the Zen "fact" which, "whatever it may be, always lands across our road like a fallen tree beyond which we cannot pass" (Merton 1995: 40). One of the expressions

5 Of course, as numerous authors point out, various forms of fundamentalisms most likely derive from a complex mix of demographic, political, and historical factors (cf. Armstrong 2001). 
of this "positively disruptive" role of religion is the anti-idolatrous use of theological language. When Gregory of Nyssa apophatically describes the true knowledge of God as "the seeing that consists in not seeing", when Karl Barth refers to God as the "Wholly Other", or when John Caputo uses the term "weakness of God" so as to untie the divine name from the "order of being" and thus release its true evental force, the paradoxical and liberating nature of theological discourse appears in abundance. A productive tension between the dogmatic and the mystical facets of religion provides another case in point. To use Buber's famous distinction (1937), while the dogmatic formulae operate on the disengaged level of "it", the accounts of mystical experiences are capable of energising and fertilising believers' connection with the transcendence addressed as "thou", and thereby infect - as it were - the order of knowledge with the transforming chaos of love.

Interestingly enough, the dialectical character of religion as an agent of (dis)order becomes most tangible at the two intersections: that of a "blessed order" (Ia) and a "cursed disorder" (IIa) as well as that of a "cursed order" (Ib) and a "blessed disorder" (IIlb). On the one hand, the objective categoricity of religiously-based principles enables a genuine religiosity to foster other-centredness in spite of the persistent threat of religious faith lapsing into a self-centred concern. On the other hand, the "domesticating" of God (the sacred) aimed at gaining power or finding a superficial comfort can be avoided due to a "Zenic function" of religious theory and praxis which positively disrupts various quasi-orders within which humans are vainly trying to confine the infinite.

\section{RELIGIOUS PLURALITY AS A SOURCE OF ORDER, FOR GOOD OR ILL}

In terms of the religious landscape of our global world, we are living in a "spiritual super-nova", a kind of galloping pluralism on the religious plane. What is essentially new about our cultural context is not the mere co-existence of many religions within modern societies (plurality), but its fragilising effects on the believers of all the world religions (pluralism) (Taylor 2007: 300; 304; 595). The multiplicity of faiths has little effect as long as it is neutralised by the sense that being like the "others" is not really - to use James's language - a "living option" for me.

Today we are witnessing the massive change in the whole background of religious beliefs, i.e., the passing of the earlier "naïve" frameworks, and the rise of the "reflective" ones. The modern homo religiosus has moved from a condition where almost everyone lived "naïvely" within his or her religious and confessional framework, to one in which we all shunt between 
numerous spiritual traditions, in which everyone's construal tends to be considered more and more "reflectively" (Taylor 2007: 14). Thus reflection on the conditions and implications, opportunities and threats of religious pluralism, which appears to be a distinguishing mark of the (post)modern thought, must continue to broaden our understanding of religiosity as such. In analogy to the previous point, let's then explore the positive and negative aspects of religious plurality, first in terms of world religions conceived of as a source of order.

IA. Religions, in their plurality, can be seen as a source of a "blessed order" if and insofar as they honestly engage in interfaith dialogue aimed at promoting global ethics which is impossible without a global ecumenism. Even though there is no consensus formula for the unity of different world religions - nor is there likely to be one in the near future "toleration, mutual respect, dialogue, and freedom for diverse testimony should be the foundation for interreligious relations" (Masciulli 2010: 68). The interfaith encounter in our age remains close to impossible unless its actors seek the way of a solidary presence rather than authoritative and pretentious proclamation, of "witness work" rather than the historical "mission work", often based on the sense of self-righteousness and exclusivity. To advance what Küng names "global ethics" - i.e., the set of values shared by people of various faiths who are committed to cooperate for the common good of all human beings, regardless of their race, gender, sexuality and beliefs - religious believers of all creeds and denominations must first engage in a transforming dialogue, directed both ad intra and ad extra, in the pursuit of what I call here a "global ecumenism".

What I mean by "global ecumenism" is, in brief, a new consciousness, primarily among believers of different religions, that stems from their shared responsibility for the future of Humanity and Earth as well as from their particular faith-perspectives, as lived and interpreted in a myriad of cultural-social contexts. Global ecumenism may enable believers to contribute towards a new world order 6 based upon an "interfaith ethic". Such an ethic, which is being developed by Küng, Knitter and others, constitutes the pivotal aspect of the world religions' contribution to that new world order. However, for that great theory to permeate the praxis of the religious believers around the globe a new "mind-set", a "global ecumenism", is needed as an extension of interfaith dialogue and collaboration. By building on the transformative achievements of the

6 Following Masciulli, by "world order" I mean the actualisation of human rights and responsibilities worldwide, the attainment of social and economic justice for our era of globalisation and the institutionalisation of global governance through the United Nations (2010: 64). 
Peace Movement, the Women's Rights Movement, the Environmental Movement, and the Ecumenical Movement, world religions - as diverse in their theory and practice as they are - have a chance to successfully build the global sense of unity-in-difference (Masciulli 2010: 73). Whether it will be the Catholic principle of subsidiarity, the Muslim teaching on the human person as the Allah's khalifah (i.e. God's "successor", "representative on earth"), or the Buddhist doctrine of the three "roots of evil" (akusalamüla): greed, anger and delusion - what matters is that religions have rich resources to provide the guiding vision for a new world order. It is critical, however, to understand that in our global context marked by a galloping religious pluralism a sense of unity can be fostered only in a way which is self-consciously not founded on any particular religion (2010: 73). Put differently, humankind can only build and maintain the common ethical and political order if religious believers representing various faiths converge on it from different points. ${ }^{7}$

IB. On the contrary, religions, in their plurality, can be seen as a source of a "cursed order" if and insofar as they deteriorate into some sort of fundamentalism - be it based on the "fortress strategy" (exclusivism) or on "conquest through embrace" (inclusivism). While religious exclusivism leads to a ghetto mentality and eventual isolation of a religious group from the wider society and the believers of other traditions, a politically correct inclusivism is more likely to preserve the appearances of dialogical openness and tolerance. However, Küng insists that what looks like tolerance often proves in practice to be "a kind of conquest by embracing, a co-optation by admission of validity, and integration through relativization and loss of identity" (1988: 236). Thus both exclusivist and inclusivist approaches may potentially harden into some kind of religious fundamentalism or fanaticism.

The common denominator of these two perversions of religious order is that each of them in one way or another deems human rationality, and especially the capacity to discern, untrustworthy. Ironically, at the same time, in all the cases God (the sacred) is rendered subject to some sort of reductionist rationalisation. Religious fundamentalists and fanatics preclude hermeneutic effort aimed at critically discerning the will of God in a given situation. Understood in a rigid and heteronomous manner, sacred texts tend to paralyse their minds, instead of stimulating them. The truth on which they claim to have a monopoly sets them free from the world but never for its sake. Established rules and codes of behaviour, which by no means dispense with the need to think of what is good and what is evil, when followed blindly, can lapse into excuses for judging and condemning

7 John Rawls' idea of an "overlapping consensus" provides a useful theoretical background for reflecting on that prospect (1999: 340). 
others and become a means of achieving absolute control over the religious subjects. Doctrine, which should serve the purpose of elucidating divine revelation here and now, tends to be reduced to a set of propositions formulated in such a way as to end all discussion and maximise certainty. And God becomes nothing more than a license to realise a particular religious (and often political) agenda. Since everything which potentially transcends the 'rigid order' is regarded with deep suspicion and puts the quasi-believers on the defensive, God must also fit into their schema or is not considered God anymore. Gamaliel's wisdom is irrelevant to religion fed by and generating such a cursed order: reading and discerning the signs of time is baseless if one knows a priori what is God's will. You cannot fill the cup that is already full.

\section{RELIGIOUS PLURALITY AS A SOURCE OF DISORDER, FOR GOOD OR ILL}

Now, I turn to the negative and positive aspects of religious plurality in terms of world religions considered as a source of disorder.

IIA. Religions, in their plurality, can be seen as a source of a "cursed disorder" if and insofar as they foster conflicts, persecutions, and discrimination on the one hand, or a "cheap tolerance" (which is nothing but "indifference in disguise") on the other. While the divisive and militant chaos brought about by those realising pseudo-religious agendas undermines the common grounds of social life and sets people against one another, a "lazy pluralism" not only has nothing to contribute to human culture, but also condemns believers to some sort of spiritual anonymity.

On the surface, treating these two phenomena jointly as expressions of the cursed disorder propelled by religions may appear illegitimate. What underlies a religiously-based violence seems to sit uneasily with the ideals preached by the proponents of what Tracy labels a "relaxed pluralism of privacies" (1981: 451). However, I want to argue that at bottom these two sorts of attitudes are congruent in that each of them stems ultimately from self-centredness which results in a failure to reach out to the hard concreteness of other religious believers. Terrorists who instrumentalise religious teachings in order to create a mood of fear for political (and ideological) reasons have absolutely no regard for the "other" who becomes an often completely innocent victim of their "deadly combination of war and theatre" (Combs 2003: 10). The hippies-like religious pluralists who uncritically approve and endorse without differentiation all the religions - though usually they have universal love and peace on their lips - de facto contribute to what Herbert Marcuse encapsulated as a 
"repressive tolerance" (1969: 95-137), wherein anyone can say anything because no one, finally, is taken seriously. Interestingly, also here God is sacrificed at the altar of a concept (such as Hick's "Ultimate Reality"), this time a concept which is inclusivist to the point of becoming abstract and unapproachable. To paraphrase the famous Heideggerian expression, before such a nameless God we can neither fall to our knees in awe nor can we play music and dance (Heidegger 2002: 72).

Of course, one ought to acknowledge that the immediate consequences of a "lazy pluralism" are not even closely as detrimental as those of religious conflicts and violence. But the establishment of peace among the world's religions cannot be reduced to the avoidance of religious wars or clashes of civilizations. The former (and unfortunately still present) military confrontation, aggression and revenge must make way for reciprocal economic and cultural cooperation, compromise and integration (Küng 2005). For that to happen, world religions ought to oppose the self-oriented "cursed disorder" which - either through open violence or through diffusing religious identity in a truth-less indifferentism - removes all grounds for an authentic dialogue and unity based on accepting the real differences and making them source of mutual growth.

IIB. On the contrary, religions, in their plurality, can be seen as a source of a "blessed disorder" if and insofar as they boldly undertake the venture of self-exposure to the other while seeking unity-indifference. To capture the full meaning of that point, in continuity with the previous one, we can refer to the historical effects of deism on the modern paradigm (immanent frame). According to the ordered and purified religion founded on reality alone (Nature and Reason) that has been introduced by Deists, God reveals Godself through creation, making demands on us which this creation itself reveals to our rational scrutiny, and also making otiose all the forms of personal relation between Creator and creatures (Taylor 2007: 292). In this context, differences between traditional religions (as opposed to the "New Religion of Humankind") are reduced to the accretions brought about by the "priestcraft" and accounted for by sinister forces which profited from darkness and ignorance. Being seen as essentially false, all these differences must be denied for the sake of returning to the simple underlying common truth (2007: 292-3). Such univocity was vainly sought by deism and, ever since, has been promoted by its modern and contemporary variations that envision a world without religion or a world of a religious syncretism based on a purported reductionist overarching principle of unity between religions. All such endeavours have been (and still are being) radically challenged by the factual plurality of religions which in our societies takes the shape 
of religious pluralism sensu stricto, with all its fragilising effects on the believers.

Based on our present level of understanding, no plausible generalisation on either commonality or complementarity or dialectical relationships between different faiths - can be made (Tracy 1991: 100; Masciulli 2010: 65). To consider the great world religions as varying conceptions of, and responses to, the one ultimate, mysterious divine reality (as in pluralism à la John Hick) is feasible only at the cost of playing down the actual and essential differences between them, which leads to what I described above as a "lazy pluralism" and thus, ultimately, relativizes all the religious truth-claims. As Tracy argues, there is no one who stands so far above all religions as to be able to judge the religious truth "objectively". Whoever thinks he can float above everything and judge it, will easily melt his waxen wings, as Icarus once did, in the sun of truth (Küng 1988: 249-50). World religions - as long as they are allowed to speak with their own diverse voices - bring a "blessed disorder" into any such attempt and thus make it clear that our real target should be not univocity, but unity-in-difference enabled by the genuine self-exposure to the other. In such perspective, the parallel "pluralism of truths" emerges, none of which is more complete than (or superior to) others, but all of which are problematic and hence open to criticism and further development in a variety of ways (Masciulli 2010: 68).

Again, we cannot fail to notice that at the intersections of a "blessed order" (IA) and a "cursed disorder" (IIA) as well as a "cursed order" (IB) and a "blessed disorder" (IIB), the complementarity of the suggested dimensions of religious plurality reveals itself at its maximum. On the one hand, the other-centred global ecumenism can embody what Schillebeeckx called "the cry for the humane" (1989: 318) and thus contribute to a new world order in a way as to prevent religiously-based violence and discrimination. It also has a function to perform in terms of opposing a "repressive tolerance" through reaching out to the hard concreteness of the other and allowing his/her différance (Derrida) to be what it is and to play the role it has to play. On the other hand, fundamentalist tendencies present in all world religions can be overcome by self-exposure to other religious believers which is capable of opening up the confessional teachings to their inherent possibilities and bringing out those possibilities anew in our pluralistic context by "grooving" with the other, by finding a rhythm with the other in genuine dia-logue (Crawford 2010: 308). 


\section{TO TRUST IN THE MIDST OF MULTI- ORDERED REALITY}

Even today religion can be conceived as an answer to the deepest human craving and a path of fulfilling the highest good. And yet when we think of the long line that runs from Aztec sacrifice, through Torquemada, to Bin Laden and the most recent atrocities committed by ISIS, religion that used to be seen as a natural vehicle of faith appears - perhaps today more than ever - as "a threat, a dangerous temptation, a distraction, or an obstacle to our greatest good" (Taylor 2007: 548). Besides, the multiplicity of religions, confessions and denominations, of religious sects, groups and movements in the world today, as well as their combination, intermingling, and opposition which can hardly be surveyed - all that is so confusing, indeed disquieting, that in the end religion often seems to contribute to what Knight labels a "new world disorder" (2010: 4; cf. also Küng 2001: 127). Consequently more people are asking where an orientation can be found in the modern disorientation, as insecurity increases with the profusion of information about diverse religions and theologies, which seem to relatizise radically one"s own religious identity (Küng 1980: 466). Thus on the one hand religion has shaped and continues to shape the ideas that undergird world order(s), but on the other it is likely to add to the overwhelming sense of chaos. Crosspressured between the open and closed perspectives on the immanent frame in which we live, humanity faces today a fundamental choice regarding the role and the meaning that religiosity will be granted in shaping a new world (dis)order. In the last analysis, whether a person is capable of seeing religion only as a menace or also as a promise seems to depend on something more primordial than the prevailing cultural expressions of a given religious tradition (Taylor 2007: 548-9). I want to suggest that this "more primordial thing" can be identified with what Küng refers to as "fundamental trust" and "fundamental mistrust" in reality as a whole.

As human beings, we are emerged in (existentially) and presented with (cognitively) uncertain reality to which we can, in principle, adopt a positive or negative attitude. This reality is identical with all that constitutes the world in space and time including other human beings and, in a special way, myself: "l" who as subject can become object to myself. Because the world is broken and the human person is all too human, we find ourselves threatened by the nothingness, transitoriness, and finiteness of all that is human and earthly. At the same time, we are somewhat inclined to say "Yes" to this uncertain reality which, when accepted trustfully, reveals to us its identity, meaning, and value. Since reality is not self-evident, an essentially free and always risky decision vis-à-vis everything that exists must be made, in which a person stakes herself without any security or 
guarantee. Thus is the basically existentialist account of what Kierkegaard named the great "Either/Or", what Ignatius Loyola in the Exercises called "electio", and what Sartre meant by "choix originel" (Urbaniak 2014a: 453; cf. also Urbaniak 2014b).

The mutual correlation between order and trust becomes evident first on the epistemological plane. Since there is no empirical method by which one's "trust in order" can be tested, to assert it is itself an act of trust, of 'anticipatory confidence' (Taylor 2007: 550). From here one may move to the ontological dimension. Berger interprets human propensity for order as one of the 'signs of transcendence' in the midst of the world and he rightly notices that it is grounded in a trust that, ultimately, reality is meaningful, i.e., "in order", "all right", "as it should be": "Faith in order is closely related to man's [sic] fundamental trust in reality" - Berger points out (1969: 71-2). My argument is that through such fundamental trust religious believers can be rescued not only from a deep disorder in their own lives, but also from suspicion towards the other believers whose interpretation of that ultimate 'orderliness' of reality, accepted in trust, differs from their own. Therefore, fundamental trust appears as a condition of the possibility of a trustful interfaith encounter, of ecumenism capable of producing an 'interreligious contribution' to a global order.

In the face of the crisis of "global trust", evident in the international political and social arenas (Soderberg 2006: 235-240), world religions may either challenge the growing climate of mistrust or contribute to it. When the universal propensity for order is approached by religious believers with fundamental mistrust, it is almost doomed to give birth to some kinds of "cursed (dis)order". The intensification of religious fundamentalisms that we observe in our day witnesses to a serious rupture in world order which rival religious actors driven by the same fundamental mistrust are vainly attempting to fill: While status quo actors ("conservatives") seek to "fortify the system's pedigree", the more radical actors ("revolutionaries") aim at revealing the system's "flawed foundations" (Philpott 2000: 206). Minorities of fundamentalist extremists present in most world religions, including different types of Christianity, who seek conflict, war and victory over other religions, render a "clash of civilizations" a fearful possibility (Huntington 1996). Of course, one can account for such phenomena by referring to historical enmity, the effects of Eurocentric colonialism, the growing globalisation which causes moderates to shrink in size (at least in some world religions), and so on. But we must not fail to notice that their ultimate reason and common denominator lies in the solidifying "culture of suspicion" (Masciulli 2010: 65). For instance, war on terrorism that for many has become "the defining paradigm in the struggle for global order" (Booth \& Dunne 2002: ix), is rooted in the religious rhetoric of mutual mistrust 
that seems to be fuelling both terrorist and counter-terrorist positioning (Knight 2010: 14-15). In such a context, Knight wonders whether organised religions - given their long history of strained and often confrontational relationships with the secular world - are still capable of promoting progress toward a peaceful world order, or will they simply "serve to aggravate global division and confrontation in an already divided world" (Knight 2010: 18).

The fact that fundamental trust constitutes one of the keys to global ecumenism, by no means implies that believers should treat their respective religions with a naïve trust. Both unconditional trust and mistrust in religion qua religion are potentially dangerous. Mistrust can easily deteriorate into a blind secularism which forces a "closed interpretation" on the modern immanent frame. Trust, in turn, is likely to lapse into either fundamentalism (if it has one particular religion, in itself, as its object) or indifferentism/ syncretism (if it concerns all the religions without any differentiation). The great monotheistic traditions share the understanding that ultimate trust cannot be put in any sort of "religious truth", but only in the divine Revealer of that truth. Put more radically, there is absolutely nothing in the world to which a person might completely entrust herself. Inherent in both Judeo-Christian and Muslim revelation is the belief that God alone has the whole truth for God alone is the absolute truth (Küng 1988: 251). In this sense, Jews, Christians and Muslims can have confidence in their religions and yet remain protected from religious fundamentalisms only insofar as they trust ultimately not in Judaism, Christianity or Islam but in "God with a name" (Yahweh for Jews, the triune God of Jesus Christ for Christians, Allah for Muslims). Only in such a way, they can trust in the midst of the multi-ordered reality of world religions while remaining genuinely religious as Jews, Christians or Muslims.

It also means that religious believers are challenged to rethink the question of truth in the spirit of freedom and responsibility rooted in their respective religious "orders", while resisting the temptation to trivialise that question and sacrifice it to the utopia of the future universal "religion of humankind". Unlike arbitrariness, freedom in religious context is not just freedom from all ties and obligations, something purely negative, but also freedom for new responsibility - toward the Earth, toward one's fellow men and women, toward oneself and toward God. The freedom, therefore, as seen by world religions, is always freedom for the truth (Küng 1988: 237). The difficult via media leads as always between the extreme of a narrowminded, conceited dogmatism which sees its own truth as detached from the truth of the others, and that of an arbitrary and irresponsible eclecticism which relativizes all truth and nonchalantly equates all values and standards (Küng 1986: xix). The only space for the growth of an authentic religiosity, 
capable of respecting the truth of others and yet faithful to its own, lies between fanaticism for truth and forgetfulness of truth. "Blind fanaticism for the truth" - Küng says -

\begin{abstract}
"has at all times and in all... religions brought unbridled violation and murder. Conversely, forgetfulness of the truth, lack of orientation, and loss of norms have meant that many people no longer believe in anything" (2001: 78).
\end{abstract}

This question of understanding "truth" in the context of religious plurality and pluralism is likely to play a decisive role in shaping a future global ecumenism.

In this paper, I presented the myriad of interpretations of religion(s) as a source of a blessed and a cursed (dis)order with the purpose of accounting for my central thesis that world religions in their ecumenical unity-indifference (i.e., as long as they reach to each other's hard concreteness in a genuine dialogue) can be entrusted with the role of contributor to a new, more just and humane global order. For that to happen, fundamental mistrust must give way to fundamental trust and naïve trust in religion to ever-challenging trust in God. This entails both freedom and responsibility for truth as well as critical discernment of how a religious truth should be embraced in action for the sake of Humanity and Earth.

I am aware that my interpretation of world religions as a source of (dis) order may at times appear to be heavily theoretical, not to say abstract. However, my point is to show that, within the conceptual framework based on Taylor's account of religiosity as a challenge to immanent frame, the notion of (dis)order, in its correlation with that of fundamental (mis)trust (Küng), can be employed as a hermeneutic key in the ecumenical and interfaith discourse, relevant to the challenges of our radically pluralistic reality. A more historically and culturally grounded reflection on how the plurality of religiously-based "orders" can be accepted and embraced with trust rather than suspicion must follow.

Let me recapitulate my reflection with Masciulli's insight on an interfaith dialoguing in the pursuit of a global responsibility:

If believers... attempt to question and answer with other (potentially) self-transcending knowers and doers in today's world context of collective practicality and co-responsibility, we need not fear the fragmentation and wars of a clash of civilizations, for we can be reasonably confident that our common transcendental cognitive and moral being will provide ample opportunities for unity, despite the human proclivity to alienation through hatred and resentment, and to rigid ideology for fear of dialogue (2010: 78). 


\section{BIBLIOGRAPHY}

Armstrong, K.

2001. The battle for God: A history of fundamentalism. New York: Ballantine Books.

BARBOUR, I.G.

1998. Religion and science: Historical and contemporary issues. London: SCM Press Ltd.

Berger, P.L.

1969. A rumour of angels: Modern society and the rediscovery of the supernatural. Garden City, N.Y.: Doubleday.

BONHOEFFER, D.

1971. Letters and papers from prison. The enlarged ed. Ed. E. Bethge. New York: The Macmillan Company.

Booth, K. \& Dunne, T.

2002. Worlds in collision: Terror and the future of global order. New York: Palgrave Macmillan.

BUBER, M.

1937. I and thou. Transl. R.G. Smith. Edinburgh: T.\&T. Clark.

CAPUto, J.D.

2001. On religion. New York: Routledge.

Combs, C.

2003. Terrorism in the twenty-first century. $3^{\text {rd }}$ ed. New Jersey: Prentice Hall.

Crawford, N.

2010. Theology as improvisation: Seeking the unstructured form of theology with David Tracy. Irish Theological Quarterly 75(3): 300-312.

FREI, H.W.

1992. Types of Christian theology. Ed. G. Hunsinger \& W.C. Placher. London: Yale University Press.

Heidegger, $\mathrm{H}$.

2002. Identity and difference: The onto-theo-logical constitution of metaphysics. Transl. J. Stambaugh. Chicago: University of Chicago Press.

HıCK, J.

1989. An interpretation of religion: Human responses to the transcendent. New Haven: Yale University Press.

Huntington, S.P.

1996. The clash of civilizations and the remaking of world order. New York: Simon \& Schuster. 
KANT, I.

2002. Theoretical philosophy after 1781. Ed. H.E. Allison, P.L. Heath. Transl. G.C. Hatfield, M. Friedman, H.E. Allison, P.L. Heath. Cambridge: Cambridge University Press [ebook].

Keightley, A.

1976. Wittgenstein, grammar and God. London: Epworth Press.

KNIGHT, A.W.

2010. Eschatology, religion and world order. Religious Studies and Theology 29(1): 1-24.

KüNG, $\mathrm{H}$.

1980. Does God exist?: An answer for today. Transl. E. Quinn. New York: Doubleday.

1988. Theology for the third millennium: An ecumenical view. Transl. P. Heinegg. New York: Doubleday.

2001. Global responsibility: In search of a new world ethic. New York: Continuum.

2005. 'In search of a global ethics'. A talk delivered at the Markkula Center for Applied Ethics at Santa Clara University, 31 March 2005 [Online] Retrieved from: [http://www.scu.edu/ethics/practicing/focusareas/global_ethics/laughlinlectures/kung-world-religions.html [2015, 26 January].

2008. On Being a Christian. Transl. E. Quinn. New York: Continuum.

Küng, H., van Ess, J., von Stietencron, H., Bechert, H. 1986 Christianity and world religions: Paths of dialogue with Islam, Hinduism, and Buddhism. Transl. P. Heinegg. Garden City, N.Y.: Doubleday.

Marcuse, $\mathrm{H}$.

1969. Repressive Tolerance. In: R.P. Wolff, B. Moore Jr., H. Marcuse (eds.). A critique of pure tolerance (Boston: Beacon Press), pp. 95-137.

Masciulli, J.

2010. Catholic Christianity and world order: A political-religious analysis. Religious Studies and Theology 29(1): 63-80.

Merton, T.

1995. Thoughts on the East. New York: New Directions Bibelot.

PhILPOTT, D.

2000. The religious roots of modern international relations. World Politics 52(2): 206-245.

RAWLS, J.

1999. A theory of justice. Revised ed. Cambridge, Mass.: Belknap Press of Harvard University Press. 
SCHILLEBEECKX, E.

1989. The role of history in what is called the new paradigm. In: H. Küng, D. Tracy (eds.). Paradigm change in theology. Transl. M. Köhl (Edinburgh: T.\&T. Clark), pp. 307-319.

Soderberg, N.E.

2006. The crisis of global trust and the failure of the 2005 world summit. Ethics \& International Affairs 20(2): 235-240.

TAYLOR, C.

1989. Sources of the self. Cambridge, Mass.: Harvard University Press.

2007. A secular age. Cambridge, Mass.: Belknap Press of Harvard University Press.

TRACY, D.

1975. Blessed rage for order. New York: Seabury Press.

1981. The analogical imagination: Christian theology and the culture of pluralism. Grand Rapids, MI.: W.B. Eerdmans.

1991. Dialogue with the other: The inter-religious dialogue. Grand Rapids, Mich.: W.B. Eerdmans.

URBANIAK, J.

2014a. 'From religionless Christianity to immanent grace: Bonhoeffer's legacy in Badiou'. Journal of Religion 94(4): 457-484.

URBANIAK, J.

2014b. 'Freed by trust, to believe together: Pursuing Global Ecumenism with Küng and Tracy'. HTS Teologiese Studies / Theological Studies 70(1), Art. \#2047, 9 pages. http://hts.org.za/index.php/HTS/article/view/2047.

Wittgenstein, L.

1958. Philosophische Untersuchungen. Oxford: B. Blackwell.

Keywords

Religion

Disorder

Order
Sleutelwoorde

Godsdiens

Wanorde

Orde 